\title{
A magyar egészségügyi rendszer teljesítményértékelése 2013-2015 jelentés összefoglalója
}

\author{
Health system performance assessment 2013-2015 report summary
}

\author{
Szerző: Formanek-Balku Eszter $\bowtie$ \\ Egészségfejlesztés folyóirat
}

Beküldve: 2017.05.31.

doi: 10.24365/ef.v58i2.153

Kulcsszavak: egészség, egészségügyi rendszer, teljesítményértékelés, MÉRTÉK

Keywords: health, healthcare, performance assessment, HSPA

\section{BEVEZETÉS}

Az egészségügy teljesítményértékelése a világon számos országában bevett szokás, melynek célja, hogy átfogó képet adjon az egészségügy működéséről. Magyarországon a teljesítményértékelés gyakorlatát a 36/2013. (V.24.) EMMI rendelet intézményesítette, és ez határozza meg a folyamat múködését is. A jogszabályban meghatározott teljesítményértékelési munka 2013-ban, a Magyar Teljesítményértékelési Munkacsoport létrejöttével kezdődött, amelynek legfőbb eredménye az itt bemutatott átfogó jelentés a 2013-2015-ös időszakról.

\section{TELESÍTMÉNYÉRTÉKELÉSI MUNKACSOPORT}

A teljesítményértékelésért felelős szerv az Állami Egészségügyi Ellátó Központ, amelyet munkájában a Munkacsoport állandó tagjai támogattak, mint az Országos Egészségügyi Pénztár, az Országos Tisztiorvosi Hivatal, a Nemzeti Egészségfejlesztési Intézet, a Központi Statisztikai Hivatal, és az Egészségügyért Felelős Államtitkárság hat főosztálya. Továbbá a közös munkában aktívan részt vettek az Egészségügyi Nyilvántartási és Képzési Központ, valamint az Országos Betegjogi, Ellátottjogi, Gyermekjogi és Dokumentációs Központ, mint meghívott tagok. Megfigyelőként volt jelen a teljesítményértékelési munkában a WHO, és módszertani segítséggel támogatta a csoport tevékenységét. A jelentés teljességéhez a tbc fókuszterület vonatkozásában, az Országos Korányi Tbc és Pulmonológiai Intézet munkatársai járultak még hozzá.

\section{JELENTÉS RÖVID ÖSSZEFOGLALÓJA}

A jelentés legfőbb célja volt, hogy a magyar egészségügyről és azon belül az ellátó rendszerről különböző forrásokból képződő nagy mennyiségű statisztikai adatokat egységes szemlélet alapján feldolgozza és az így kapott eredményeket interpretálja különböző szakmai ismereti szinteken. A jelentés tartalma az előzetesen meghatározott indikátorok bemutatására épült, amelyek a következő témakörökbe sorolhatóak:

- Az egészségi állapot egészségügyön kívüli befoIyásoló tényezői;

- Demográfiai, mortalitási és morbiditási adatok;

- Struktúra/elérés;

- Pénzügyi védelem; 
- Minőség, ellátásbiztonság;

- Hatékonyság, fenntarthatóság;

- Fókuszterületek: Szívinfarktus és tuberkolózis ellátás.

Bár a jelentés készítése során alkalmazott, átfogó megközelítés az egyes indikátorokkal kapcsolatos vizsgálat részletességének határt szab, a közölt adatok, feltárt problémák, és mélységi elemzések további program- és intézményértékelések és egyéb szakpolitikai munkák kiindulópontjai lehetnek.

A jelentésben részletesen tárgyalt eredmények alapján összességében megállapítható, hogy bár a magyar lakosság egészségi állapota javuló tendenciát mutat, továbbra is elmarad az Európai Unió legtöbb tagállamának szintjétől. Az alacsony gazdasági státuszú háztartásoknak gyakran jelentős anyagi terhet okoz az egészségügyi ellátáshoz való hozzáférés. Az ellátórendszer múködésében mind a hozzáférés, mind a minőség, mind pedig a hatékonyság területén számos olyan problémát azonosítottak, amelyek megoldásával a fenti nehézségek számottevő mértékben javíthatóak lennének. Fontos kiemelni, hogy az egészségi állapotot nem csak az ellátórendszer befolyásolja, hanem az azon kívül eső tényezők, mint az egészségmagatartás, ezért ezen a területen történő beavatkozásokra is sokkal nagyobb hangsúlyt kell fektetni.

$\mathrm{Az}$ indikátorok részletes eredményeiért és további érdekes információkért keresse fel a MÉRTÉK honlapját: $\quad$ https://mertek.aeek.hu/web/mertek-magyar-egeszsegugyi-rendszer-teljesitmenyertekelese 